\title{
Ecological Indices of the Heavy Metals in the Soil of Shewasoor Sub-Basin, Kirkuk NE Iraq
}

\author{
Mustafa Jamal Akbar Ali ${ }^{1 *}$, Omer S Al-Tamimi ${ }^{1}$ \\ ${ }^{1}$ University of Kirkuk, Iraq \\ *Corresponding author: Mustafa Jamal Akbar Ali: \\ mustafa.jamalakbar77@gmail.com
}

\section{Abstract:}

Citation: Ali M.J.A , Al-Tamimi O.(2018) Ecological Indices of the Heavy Metals in the Soil of Shewasoor Sub-Basin, Kirkuk NE Iraq. Open Science Journal 3(1)

Received: $24^{\text {th }}$ December 2017

Accepted: $22^{\text {nd }}$ February 2018

Published: $27^{\text {th }}$ March 2018

Copyright:@ 2018 This is an open access article under the terms of the Creative Commons

Attribution License, which permits unrestricted use, distribution, and reproduction in any medium, provided the original author and source are credited.

Funding: The author(s) received no specific funding for this work

Competing Interests: The author have declared that no competing interests exists.
The current research aimed to assess contamination levels in the soil of study area by heavy metals. Eight sites were selected for the collection of soil samples. The eight heavy metals namely As, $\mathrm{Pb}, \mathrm{Cd}, \mathrm{Cr}, \mathrm{Co}, \mathrm{Cu}, \mathrm{Ni}$, and $\mathrm{Zn}$ were analyzed in each soil samples by using ICP-MS technology. The measured concentrations of heavy metals were compared with Geochemical Background values, EPA Sediment Quality Guidelines, Ecological Screening values, and WHO Guidelines. The spatial distribution maps of ecological indices were performed using ArcGIS software (version 10.2), which provides an idea of the geographical distribution of heavy metals contamination levels in the soil of Shewasoor sub-basin. The soil contamination by heavy metals assessed using Potential Ecological Risk Index $(R I)$, Nemerow Pollution Index $\left(P_{N}\right)$, Hazard Index $(H I)$, and Cancer Risk. The RI showed there are high risk of heavy metals in soil and according to $P_{N}$ the soil has been moderate to severely contaminated by heavy metals. The hazard index of all soil samples was within acceptable range for adults and showed unacceptable risk for children. While the total cancer risk values of $\mathrm{As}$ and $\mathrm{Cr}$ were within acceptable limits, whereas of $\mathrm{Pb}, \mathrm{Cd}$, $\mathrm{Co}$, and $\mathrm{Ni}$ were lower than acceptable risk range at all sites for adults and children. Ecological indices which are used to assess the contamination levels in the soil by heavy metals refers to the soil of study area was contaminated moderate to heavily by heavy metals, this attributed to the natural and anthropogenic pollution sources around and within the study area. 
Keywords: Ecological, Indices, Heavy Metals, Soil, Shewasoor Sub-basin.

\section{Introduction}

The soil is an important component of terrestrial ecosystems, it's very sensitive to environmental change. the soil can contaminate by introducing of pollutants from different pathways $[1,2]$. The contribution of heavy metals from anthropogenic sources in soil is higher than the contribution from natural sources [3]. The soil contamination with heavy metals is of one the most ecological problems because it's related directly to the human health. [4-6]. The heavy metals are dangerous pollutants unlike other pollutants because they are nondegradable for that accumulate in the soil, the effects of these metals may be reflected in the plant behavior, microbiological processes and transfer of toxic levels of the elements to man and animals, these elements have negative effects on human health and on the environment especially on the children [7-12]. Some heavy metals play an essential role in biochemical processes, most organisms required these metals in a small amount for normally healthy growth (e.g. Zn, $\mathrm{Cu}$, and $\mathrm{Cr}$ ) [1], but become toxic at higher concentration [13]. Other heavy metals are not essential and do not cause deficiency disorders if absent (e.g. Cd, $\mathrm{Pb}$, and $\mathrm{As}$ ), these metals toxic at low levels of exposure $[1,14]$. Absorption of heavy metals by the body for a period of time (years or decades) lead to accumulation these metals in vital organs like brain, liver, bones, and kidneys, then causing serious health consequences [14]. Hence, the study of heavy metals pollution in soil and assess its environmental risks to the agricultural products and human health very important and necessary [15]. The current research aimed to 1) Determine the concentration of heavy metals in the soil of Shewasoor subbasin. 2) Ecological assessment of the soil of Shewasoor sub-basin using Potential ecological risk index, Nemerow pollution index. 3) Assessment of the potential health risks of heavy metals on the population in the study area by an estimate carcinogenic risk and non-carcinogenic hazard.

\section{Study Area}

The study area is located to the northeastern part of Iraq, between (454999.1 $\mathrm{mE}-471002.3 \mathrm{mE})$ and $(3949735.6 \mathrm{mN}-3968762.3 \mathrm{mN})$, apart about $39 \mathrm{Km}$ to the north east of Kirkuk city, covers about $160 \mathrm{Km}^{\wedge} 2$. The study area is bounded by Taqtaq Anticline from north and northeast sides, by Northern ChamChamal Anticline from west and southwest sides, and by topographic elevated area from south and southeast sides. Also, the topographic elevations of the study area ranges between (311-1186) m a.s.l. (Figure 1). The climate of Iraq is generally continental type, its cold rainy in the winter and hot and dry in the summer [16]. 


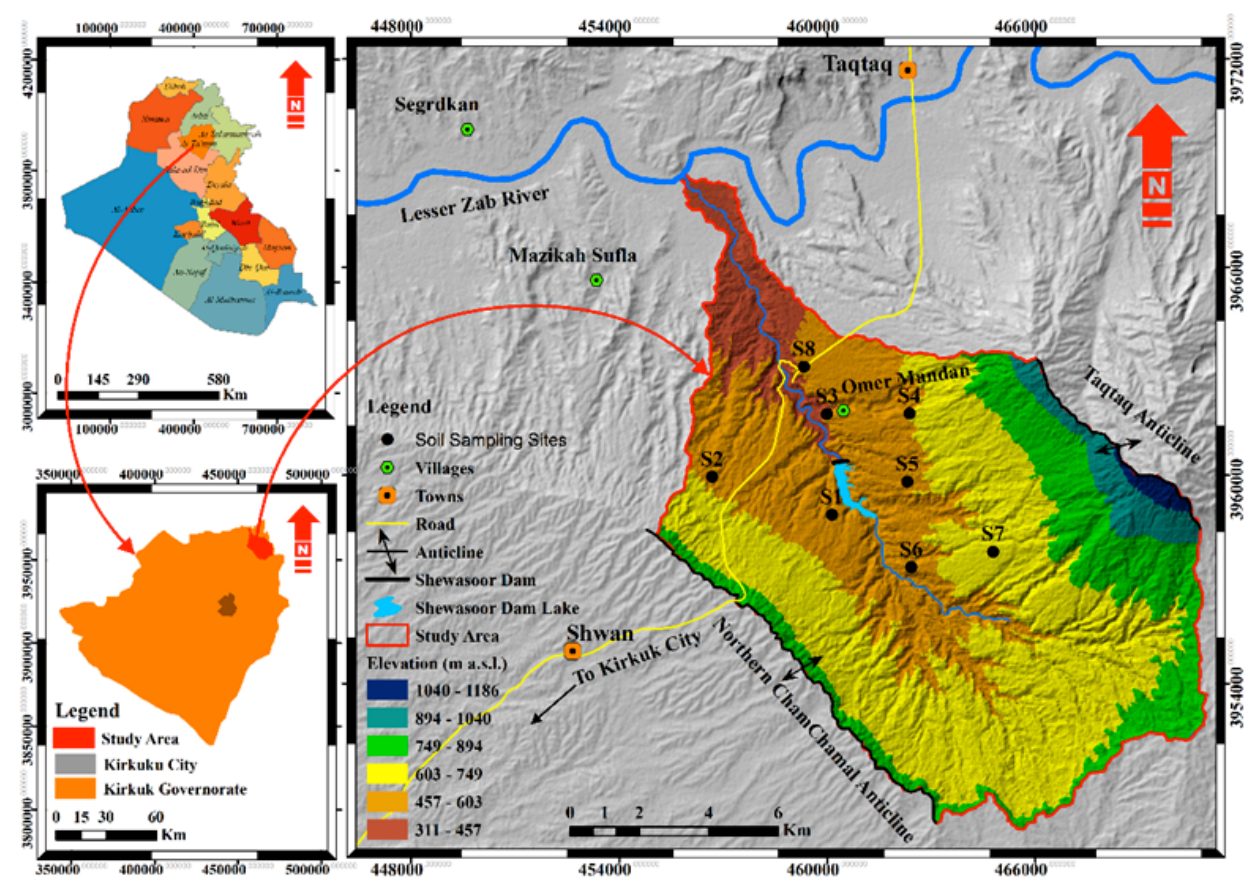

Figure 1. Location Map of Study Area and Soil Sampling Sites.

\section{Geological Setting and Tectonic}

The exposed formations in the study area extending from oldest (Upper Miocene) up to youngest (Quaternary deposits) [17], (Figure 2) are:

Injana Formation: (Upper Miocene), it consists of gray, brown sandstone, brown claystone and siltstone of the same colour [17]. The thickness of this formation is $2000 \mathrm{~m}$ in the center of depositional basin within Foothill zone [18].

Mukdadiya Formation: (Uppermost Miocene-Pliocene), it consists of brown claystone with gray coarse-grained sandstone, brown and gray siltstone, and pebbly sandstone [17]. Its thickness is more than $2500 \mathrm{~m}$ in the center of the depositional basin within Foothill zone [18].

Bai-Hassan Formation: (Pliocene), it consists of thick and coarse conglomerates, thick brown claystone and thin sandstone [17]. Its thickness is more than $2000 \mathrm{~m}$ in the center of depositional basin within Foothill zone [18].

Quaternary Deposition: (Pliocene-Holocene), Six types of quaternary deposits are developed in the study area, are River terraces, Polygenetic deposits, Slope deposits, Residual gravels, Floodplain, and Valley-fill deposits [17].

Tectonically the study area lies in the Unstable shelf within Foothill zone in Chamchamal-Arbil subzone according to tectonic division of Iraq [19]. 


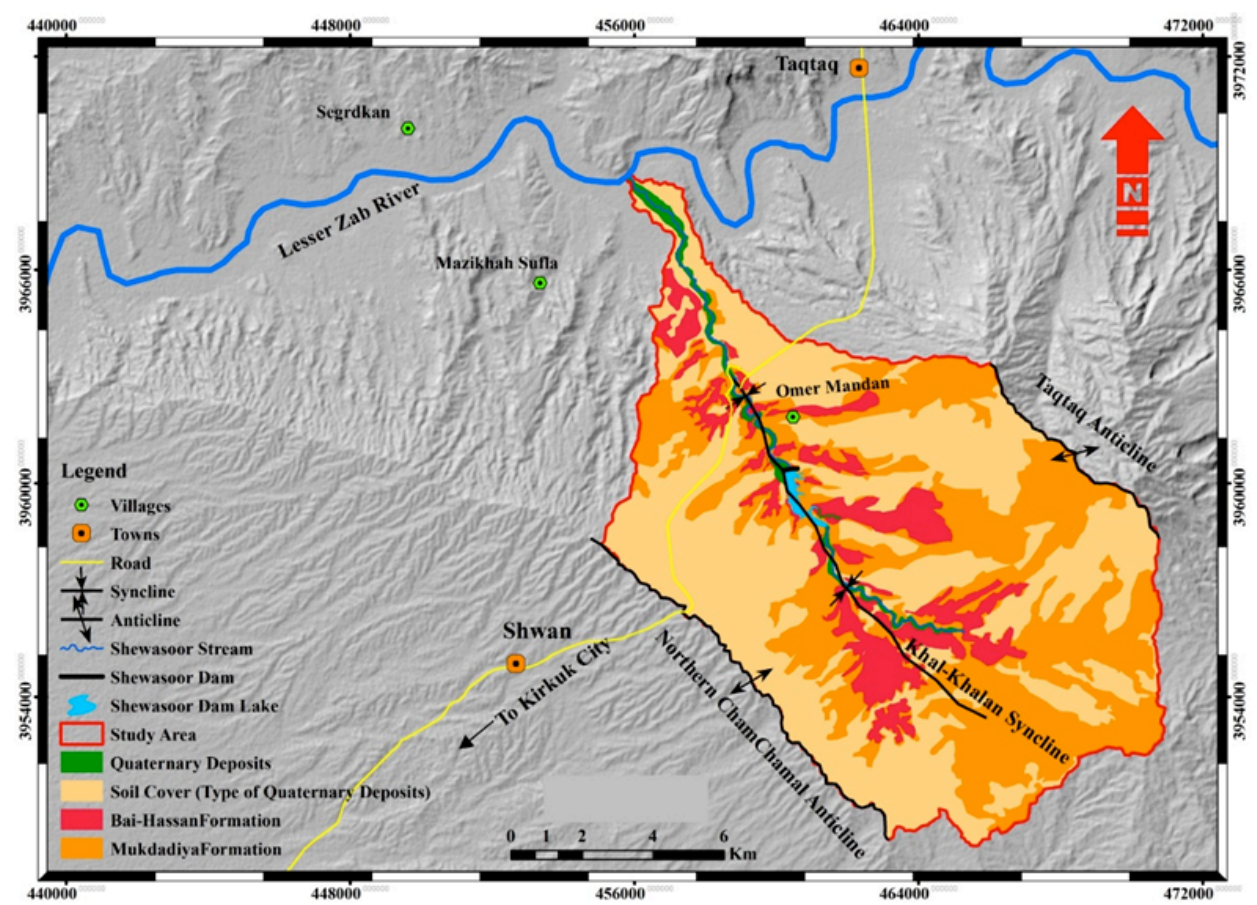

Figure 2. Geological Map of Study Area

\section{Soil of the Study Area}

The study area represents deep valley contain ephemeral stream coming down from the high areas. The soil of the study area formed as a result of intensive erosion processes of rock formations that are exposed at the surface mainly BaiHassan and Mukdadiya Formations. Two soil types were recognized in the area are [20]:

Reddish-Brown Soil: This type of soil represents the hill slopes soils, which is characterized by reddish-brown surface soil which at little depth turns up from brown colour into red colour, lime accumulation begins at depth $15 \mathrm{~cm}$, also its soft soil easily eroded, the biological activity and chemical weathering are rather low, and its highly permeable soil causing infiltration of water into subsurface.

Brown Soil: This soil has a brown surface layer of about (25-30) cm, grading into a brownish-gray to the whitish horizon of lime accumulation, which consists of silt loam mixed with some gravels, grading into brown silt loam at $14 \mathrm{~cm}$, with lime accumulation beginning at a depth of $30 \mathrm{~cm}$. The topsoil is alkaline and may have ( 1 or 2 ) $\%$ of organic matter. The process of chemical weathering becomes more important in this type of soil.

\section{Materials and Methods}

\section{Sampling and Analysis}

Collection of Samples: Soil samples were collected from eight sites within the study area as shown in (Figure 1) at Oct 2016. Before the sampling (Fieldwork) start, the stratified random sampling method was selected, where the 
study area is divided into a grid of egalitarian squares and soil samples were taken randomly from each square from (0-20) $\mathrm{cm}$ depth, the samples were placed in clean and new polythene bags. The large empty area in the sampling map represent the geological outcrops.

Preparation of Samples: Soil samples were air-dried at room temperature and sieved by (200 mesh) sieve in order to separate and remove all course materials. The weighted $2 \mathrm{gm}$ of samples and placed in small polythene bags, then they were transferred to the laboratory.

Analysis of Samples: The eight heavy metals $\mathrm{As}, \mathrm{Pb}, \mathrm{Cd}, \mathrm{Cr}, \mathrm{Co}, \mathrm{Cu}, \mathrm{Ni}$, and $\mathrm{Zn}$, were analyzed in all samples. The concentrations of heavy metals were determined using Inductively Coupled Plasma-Mass Spectrometry (ICP-MS) at Acme labs/ Vancouver, BC Canada V6P 6E5. The physicochemical characteristics of soil samples were analyzed in the Environmental Research Unit Laboratory/ College of Science/ University of Kirkuk.

\section{Statistical Analysis}

The calculation of descriptive statistical parameters (median, average, max, and min) and Pearson's correlation coefficients analysis were performed between heavy metals using the SPSS software, version 22 .

\section{Spatial Distribution Analysis}

The spatial distribution maps of ecological indices were mapped (scale 1:88000) carried through Inverse Distance Weighted (IDW) method by using ArcGIS software (version 10.2).

\section{Ecological Assessment Methods}

The ecological assessment of the soil of Shewasoor sub-basin was performed by using the following ecological indices:

\section{Nemerow Pollution Index $\left(\boldsymbol{P}_{N}\right)$ :}

The Nemerow pollution index $\left(P_{N}\right)$ was used to assess the total contamination level of heavy metals in the soil of study area and evaluate environment quality. The Nemerow pollution index was calculated by using the following equation [21], see (Table 1):

$$
\begin{aligned}
& P I=\frac{c_{n}}{S_{n}} \\
& P_{N}=\sqrt[2]{\left(P I_{\text {max }}\right)^{2}+\left(P I_{\text {averags }}\right)^{2} / 2}
\end{aligned}
$$

Where: $P I$ is Pollution Index of heavy metal $(\mathrm{n}), C_{n}$ is Measured concentration of heavy metal (n), $S_{n}$ is Background concentration of heavy metal (n), according to [22] (Table 5), $P_{N}$ is Nemerow pollution index, $P I_{\max }$ is Maximum pollution 
index value for all of the pollutant, $P I_{\text {average }}$ is Average pollution index value for all of the pollutant.

Table 1: Nemerow Pollution Index $\left.\left(P_{N}\right)\right)$ and Contamination Level [21].

\begin{tabular}{|l|l|}
\hline$P_{N \text { value }}$ & Contamination Level \\
\hline$P_{N \leq 1}$ & Soil has not been contaminated \\
\hline $1<P_{N} \leq 2$ & Soil has been slightly contaminated \\
\hline $2<P_{N} \leq 3$ & Soil has been moderately contaminated \\
\hline$P_{N>3}$ & Soil has been severely contaminated \\
\hline
\end{tabular}

\section{Potential Ecological Risk Index $(R I)$}

The contaminated soil with heavy metal can enter the human body through several pathways and various exposure approaches [23]. Elevated levels of toxic heavy metals in agricultural soil can influence food chain, hence lead to increase the exposure of severing dangerous diseases, such as cancer, leukemia, and kidney or liver damage [24]. Therefore, the assessment of potential ecological risks $(R I)$ is necessary, which developed by [25], represent the toxicity of heavy metals and their risks level to the environment, $(R I)$ value is calculated by the following [25], see (Table 2):

$R I=\sum_{i=1}^{n} \frac{\left(T_{i} * C_{i}\right)}{B_{i}}$

Where: $T_{i}$ is Toxicity factor of heavy metals are $(\mathrm{Cd}=30, \mathrm{As}=10, \mathrm{~Pb}=5$, $\mathrm{Cu}=5, \mathrm{Cr}=2, \mathrm{Zn}=1, \mathrm{Ni}=5), C_{i}$ is Measured concentration of heavy metal $(i), B_{i}$ is Background concentration of heavy metal $(i)$ (Table 5) [22].

Table 2: Potential Ecological Risk Index (RI) and Level of Risk [25].

\begin{tabular}{|l|l|}
\hline$R I$ value & Risk Level \\
\hline$R I \leq 50$ & Low risk \\
\hline $50<R I \leq 100$ & Moderate risk \\
\hline $100<R I \leq 150$ & High risk \\
\hline $150<R I \leq 200$ & Very high risk \\
\hline $200<R I$ & Extreme risk \\
\hline
\end{tabular}

\section{Health Risk Assessment}

Health risk assessment was employed to estimate the adverse health effects of exposure to the carcinogenic and non-carcinogenic heavy metals on the human health [26]. The risk assessment consisted of four basic steps [26,27]: hazard identification, exposure assessment, toxicity (dose-response) assessment, and risk characterization. 
A) Chronic Daily Intake $(C D I)$ :

The human can expose to heavy metals in soil through three pathways are [28]: 1) Ingestion of soil 2) Dermal absorption of heavy metals 3) Inhalation of heavy metals that emitted with soil particles. The Chronic Daily Intake $(C D I)$ of heavy metals in the soil of study area by three pathways was calculated by using the following equations [28], see (Table 3):

For non-carcinogenic:

$$
\begin{aligned}
& C D I_{\text {ing }-n c}=\frac{C_{s o i l} * \operatorname{Ing} R * E F * E D * C F}{B W * A T_{n c}} \\
& C D I_{\text {dermal }-n c}=\frac{C_{s o i l} * S A * A F * A B S * E F * E D * C F}{B W * A T_{n c}} \\
& C D I_{\text {inh }-n c}=\frac{C_{s o i l} * I n h R * E F * E D}{P E F * B W * A T_{n c}}
\end{aligned}
$$

For carcinogenic:

$$
\begin{aligned}
& C D I_{\text {ing }-c}=\frac{C_{\text {soil }} * \operatorname{Ing} R * E F * E D * C F}{B W * A T_{r}} \\
& C D I_{\text {dormal }-c}=\frac{C_{s o i l} * S A * A F * A B S * E F * E D * C F}{B W * A T_{c}} \\
& C D I_{\text {inh }-c}=\frac{C_{s o i l} * \operatorname{Inh} R * E F * E D}{P E F * B W * A T_{r}}
\end{aligned}
$$

Where: $C D I_{\text {ing }}, C D I_{\text {dermal }}$, and $C D I_{\text {inh }}$ were the chronic daily intake through ingestion of soil (mg/kg-day), dermal contact with soil particles $(\mathrm{mg} / \mathrm{kg}$ day), and inhalation of heavy metals via soil particles $\left(\mathrm{mg} / \mathrm{m}^{3}\right.$ for noncarcinogenic and $\mu \mathrm{g} / \mathrm{m}^{3}$ for carcinogenic), and other parameters are clarified in (Table 3). 
Table 3: Parameters Used in the Health Risk Assessment of Soil of Study Area for Adult and Children [29,30].

\begin{tabular}{|c|c|c|c|}
\hline Parameter & Unit & Adult & Child \\
\hline Concentration of metals $\left(C_{\text {soil }}\right)$ & ppm & - & - \\
\hline Exposure Duration $(E D)$ & year & 30 & 6 \\
\hline Exposure Frequency $(E F)$ & days/ year & 350 & 350 \\
\hline Ingestion Rate $(\operatorname{IngR})$ & $\mathrm{mg} /$ day & 100 & 200 \\
\hline Inhalation Rate $(\operatorname{InhR})$ & $\mathrm{m}^{3} /$ day & 20 & 10 \\
\hline Body Weight $(B W)$ & $\mathrm{kg}$ & 70 & 15 \\
\hline $\begin{array}{l}\text { Average Time }(A T) \text { : } \\
\text { For Non-carcinogenic } \\
\text { For Carcinogenic }\end{array}$ & days & $\begin{array}{l}\mathrm{ED} * 365 \\
70 * 365\end{array}$ & $\begin{array}{l}\mathrm{ED} * 365 \\
70 * 365\end{array}$ \\
\hline Conversion Factor $(C F)$ & $\mathrm{kg} / \mathrm{mg}$ & $10^{-6}$ & $10^{-6}$ \\
\hline Skin Surface Area $(S A)$ & $\mathrm{cm}^{2}$ & 5700 & 2800 \\
\hline Soil Adherence Factor $(A F)$ & $\mathrm{mg} / \mathrm{cm}^{2} \cdot$ day & 0.07 & 0.2 \\
\hline $\begin{array}{lll}\begin{array}{l}\text { Particle } \\
(P E F)\end{array} & \text { Emission } & \text { Factor } \\
\end{array}$ & $\mathrm{m}^{3} / \mathrm{kg}$ & $1.4^{*} 10^{9}$ & $1.4^{*} 10^{9}$ \\
\hline $\begin{array}{l}\text { Dermal Absorption } \quad \text { Factor } \\
(A B S)\end{array}$ & - & \multicolumn{2}{|c|}{$\begin{array}{l}0.03 \text { for As and } 0.001 \text { for } \\
\text { other elements }\end{array}$} \\
\hline
\end{tabular}

B) Non-carcinogenic Risk Assessment:

The non-carcinogenic risk evaluated by using the hazard quotient $(H Q)$. $H Q$ value indicates the degree of exposure $(C D I)$ greater or less than the $(R f D)$. The $H Q$ value represents the ratio of $A D I$ to $R f D$ of the toxic metals in soil samples were calculated by using the following equation [28], see (Table 4):

$$
T H Q=H Q_{i n g}+H Q_{d r m a l}+H Q_{i n h}=\frac{C D I_{\text {ing } n c}}{R f D_{i n g}}+\frac{C D I_{\text {dermal }-n c}}{R f D_{\text {dermal }}}+\frac{C D I_{\text {inh }-n c}}{R f C_{\text {in } h}}
$$

Where: $T H Q$ is Total Hazard Quotient, $H Q_{\text {ing }}$ is Ingestion Hazard Quotient, $H Q_{\text {drmal }}$ is Dermal Hazard Quotient, $H Q_{i n h}$ is Inhalation Hazard Quotient $C D I_{\text {ing-nc }} C D I_{\text {dermal-nc }}$ and $C D I_{\text {inh-nc }}$ were non-carcinogenic chronic daily intake through three pathways ingestion ( $\mathrm{mg} / \mathrm{kg}$-day), dermal (mg/kg-day), and inhalation $\left(\mathrm{mg} / \mathrm{m}^{3}\right)$, respectively, $R f D_{\text {ing }}, R f D_{\text {dermal }}$, and $R f C_{\text {inh }}$ were Ingestion Reference Dose (mg/ kg-day), Dermal Reference Dose $\left(R f D_{i n g}{ }^{*}\right.$ Fraction of contaminant absorbed in the skin $\left.\left(A B S_{G I}\right)\right)(\mathrm{mg} / \mathrm{kg}$-day), and Inhalation Reference Concentration $\left(\mathrm{mg} / \mathrm{m}^{3}\right)$, respectively.

The hazard index $(H I)$ estimated the risk of a mixture of contaminant (e.g. Heavy metal), which represents the sum of more than one $H Q$ for heavy metals, the $H I$ calculated by using the following equation [28]:

$$
H I=\sum T H Q
$$

Where, $T H Q$ and $H I$ are total hazard quotient and hazard index, respectively. If the $H I$ value is less than one $(H I<1)$ mean there is no noncarcinogenic risks, if the $H I$ value exceeds one $(H I>1)$ mean there is noncarcinogenic adverse effects [28]. 
C) Carcinogenic Risk Assessment:

Cancer risk estimates the probability of an individual lifetime health risk as a result of exposure to the carcinogens. The cancer risk calculated by using the following equation [28], see (Table 4):

$$
\begin{aligned}
& \text { Total Cancer Risk }=\text { Risk }_{\text {ing }}+\text { Risk }_{\text {dermal }}+\text { Risk }_{\text {inh }} \\
& =C D I_{\text {ing-c }} * C S F_{\text {ing }}+C D I_{\text {dermal }-c} * C S F_{\text {dermal }}+C D I_{\text {inh }-c} * I U R
\end{aligned}
$$

Where: Risk $_{\text {ing }}$, Risk $_{\text {dermal }}$, and Risk $_{\text {inh }}$ are cancer risks through ingestion, dermal, and inhalation pathways, $C S F_{\text {ing }}, C S F_{\text {dermal }}$, and IUR are ingestion chronic slope factor ( $\mathrm{mg} / \mathrm{kg}$-day) ${ }^{-1}$, dermal chronic slope factor $\left(C S F_{\text {ing }} / A B S_{G I}\right)(\mathrm{mg} / \mathrm{kg} \text {-day })^{-1}$, and inhalation unit risk $\left(\mu \mathrm{g} / \mathrm{m}^{3}\right)^{-1}$, respectively. The acceptable or tolerable total risk for regulatory purposes is in the range of $\left(10^{-6}-10^{-4}\right),[30,32]$.

Table 4: Parameters Used for the Non-carcinogenic Hazard and Carcinogenic Risk. Assessment of Study Area Soil for Adult and Children. [30].

\begin{tabular}{|c|c|c|c|c|c|c|c|}
\hline Metal & RfD $_{\text {ing }}$ & RfD $_{\text {dermal }}$ & RfC $_{\text {inh }}$ & CSF $_{\text {ing }}$ & CSF $_{\text {dermal }}$ & IUR & $A B S_{G I}$ \\
\hline $\mathrm{As}$ & $3^{*} 10^{-4}$ & $3^{*} 10^{-4}$ & $1.5^{*} 10^{-5}$ & 1.5 & 1.5 & $4.3^{*} 10^{-3}$ & 1 \\
\hline $\mathrm{Pb}$ & $3.5^{*} 10^{-3}$ & $3.5^{*} 10^{-3}$ & - & $8.5^{*} 10^{-3}$ & $8.5^{*} 10^{-3}$ & $1.2^{*} 10^{-5}$ & 1 \\
\hline $\mathrm{Cd}$ & $5^{*} 10^{-4}$ & $2.5^{*} 10^{-5}$ & $1^{*} 10^{-5}$ & - & - & $1.8^{*} 10^{-3}$ & 0.05 \\
\hline $\mathrm{Cr}$ & $3^{*} 10^{-3}$ & $7.5^{*} 10^{-5}$ & $1^{*} 10^{-4}$ & $5^{*} 10^{-1}$ & 20 & $8.4^{*} 10^{-2}$ & 0.025 \\
\hline $\mathrm{Co}$ & $3^{*} 10^{-4}$ & $3^{*} 10^{-4}$ & $6^{*} 10^{-6}$ & - & - & $9^{*} 10^{-3}$ & 1 \\
\hline $\mathrm{Cu}$ & $4^{*} 10^{-2}$ & $4^{*} 10^{-2}$ & - & - & - & - & 1 \\
\hline $\mathrm{Ni}$ & $2^{*} 10^{-2}$ & $8^{*} 10^{-4}$ & $9^{*} 10^{-5}$ & - & - & $2.6^{*} 10^{-4}$ & 0.04 \\
\hline $\mathrm{Zn}$ & $3^{*} 10^{-1}$ & $3^{*} 10^{-1}$ & - & - & - & - & 1 \\
\hline
\end{tabular}

\section{Results and Discussion}

\section{Concentrations of Heavy Metals in Soil Samples}

The concentration of heavy metals in the Shewasoor's sub-basin soil shown in (Table 5). The abundance trend of median concentrations of heavy metals in the soil samples in order of $\mathrm{Ni}>\mathrm{Cr}>\mathrm{Zn}>\mathrm{Cu}>\mathrm{Co}>\mathrm{Pb}>\mathrm{As}>\mathrm{Cd}$, the concentrations of $\mathrm{As}, \mathrm{Cd}$, and $\mathrm{Ni}$ in the all samples highest than geochemical background values, while the concentrations of $\mathrm{Pb}, \mathrm{Cr}$, $\mathrm{Co}$, and $\mathrm{Zn}$ in all samples lower than geochemical background values, except $\mathrm{Zn}$ at site (S7), higher than same value. The concentration of $\mathrm{Cu}$ at (S1, S2, and $\mathrm{S} 4)$ lower than geochemical background value, but its concentration higher than the compared value at other sites.

According to Ecological Screening values [33] (Table 5), the concentrations of $\mathrm{As}, \mathrm{Pb}, \mathrm{Cd}$, and $\mathrm{Cu}$ are lower than Ecological Screening values, while the concentrations of $\mathrm{Cr}$, Co, and $\mathrm{Ni}$ are higher than the Ecological Screening values at all soil sampling sites. But Zn at sites (S1, S2, and S4) is lower than Ecological Screening value and at other sites its concentration higher than the same value. 
The concentrations of $\mathrm{As}, \mathrm{Pb}, \mathrm{Cd}, \mathrm{Cr}, \mathrm{Co}, \mathrm{Cu}$, and $\mathrm{Zn}$ at all sites did not exceed the WHO Guidelines [34], except the Ni, exceeded the same guidelines (Table 5).

Table 5: Concentrations of Heavy Metals in Soil Samples of Study Area, Geochemical Background values of Heavy Metals, and Maximum Allowable Limit of Concentrations of Heavy Metals in Soil for Several Guidelines. (ppm)

\begin{tabular}{|c|c|c|c|c|c|c|c|c|c|}
\hline Site Name & As & $\mathrm{Pb}$ & $\mathrm{Cd}$ & $\mathrm{Cr}$ & $\mathrm{Co}$ & $\mathrm{Cu}$ & $\mathrm{Ni}$ & $\mathrm{Zn}$ & $\mathrm{pH}$ \\
\hline $\mathrm{S} 1$ & 6.7 & 10.07 & 0.25 & 79.8 & 17.6 & 23.15 & 118 & 49.2 & 7.5 \\
\hline $\mathrm{S} 2$ & 5.3 & 8.08 & 0.17 & 61.6 & 20.2 & 25.56 & 94.5 & 36.1 & 7.7 \\
\hline S3 & 8.7 & 13.56 & 0.15 & 78.4 & 19.1 & 29.98 & 129.7 & 56.7 & 8 \\
\hline $\mathrm{S} 4$ & 9.7 & 10.92 & 0.16 & 64.6 & 14.4 & 19.55 & 82 & 39.4 & 8 \\
\hline S5 & 7.3 & 11.53 & 0.15 & 69.5 & 16.3 & 25.08 & 108.9 & 52.5 & 8.1 \\
\hline $\mathrm{S} 6$ & 6.9 & 12.59 & 0.27 & 80.1 & 17.1 & 27.77 & 132 & 57 & 7.8 \\
\hline $\mathrm{S} 7$ & 7.1 & 14.66 & 0.27 & 99.1 & 21.8 & 33.72 & 143.2 & 76 & 7.9 \\
\hline $\mathrm{S} 8$ & 6.1 & 11.29 & 0.27 & 79.1 & 17.5 & 27.39 & 128.9 & 51.2 & 8.2 \\
\hline Median & 7.0 & 11.41 & 0.21 & 78.75 & 17.55 & 26.475 & 123.45 & 51.85 & 7.95 \\
\hline Average & 7.225 & 11.587 & 0.211 & 76.525 & 18 & 26.525 & 117.15 & 52.263 & 7.9 \\
\hline Min & 5.3 & 8.08 & 0.15 & 61.6 & 14.4 & 19.55 & 82 & 36.1 & 7.5 \\
\hline Max & 9.7 & 14.66 & 0.27 & 99.1 & 21.8 & 33.72 & 143.2 & 76 & 8.2 \\
\hline $\begin{array}{l}\text { Geochemical Background } \\
\text { Value }^{\text {a }}\end{array}$ & 1.7 & 14.8 & 0.1 & 136 & 24 & 25 & 56 & 65 & - \\
\hline $\mathrm{EPA}^{\mathrm{b}}$ & 10 & 16 & 0.38 & 0.4 & 9 & 36 & 30 & 50 & - \\
\hline WHO Guidelines ${ }^{c}$ & 20 & 100 & 3 & 100 & 50 & 100 & 50 & 300 & - \\
\hline
\end{tabular}

The heavy metals concentrations in the soil of study area were assessed by comparing with the EPA Sediment Quality Guidelines (SQGs) [35] shown in (Table 6). The results showed all sites are non-polluted with $\mathrm{Pb}, \mathrm{Cd}$, and $\mathrm{Zn}$, but polluted heavily by $\mathrm{Ni}$, the soil at $\mathrm{S} 6, \mathrm{~S} 7$, and $\mathrm{S} 8$ is polluted moderately with As and $\mathrm{Cu}$, whereas polluted heavily by $\mathrm{Cr}$. also the S5 and S2 considered as polluted moderately by $\mathrm{As}, \mathrm{Cr}$, and $\mathrm{Cu}$, while $\mathrm{S} 3$ showed heavy pollute by $\mathrm{As}$ and $\mathrm{Cr}$ and moderate pollute for $\mathrm{Cu}$. The moderate pollution observed at $\mathrm{S} 1$ for As, and heavy pollution for $\mathrm{Cr}$, but it non-polluted with $\mathrm{Cu}$, as well as $\mathrm{S} 4$ heavily polluted by As, and exhibit moderate pollute with $\mathrm{Cr}$, also it non-polluted by $\mathrm{Cu}$.

Table 6: EPA Sediment Quality Guidelines (SQGs) [35].

\begin{tabular}{|l|l|l|l|l|}
\hline Metal & Non-polluted & $\begin{array}{l}\text { Moderately } \\
\text { Polluted }\end{array}$ & $\begin{array}{l}\text { Heavily } \\
\text { Polluted }\end{array}$ & Present Study \\
\hline $\mathrm{As}(\mathrm{ppm})$ & $<3$ & $3-8$ & $>8$ & $5.3-9.7$ \\
\hline $\mathrm{Pb}(\mathrm{ppm})$ & $<40$ & $40-60$ & $>60$ & $8.08-14.66$ \\
\hline $\mathrm{Cd}(\mathrm{ppm})$ & $*$ & $*$ & $>6$ & $0.15-0.27$ \\
\hline $\mathrm{Cr}(\mathrm{ppm})$ & $<25$ & $25-75$ & $>75$ & $61.6-99.1$ \\
\hline $\mathrm{Cu}(\mathrm{ppm})$ & $<25$ & $25-50$ & $>50$ & $19.55-33.72$ \\
\hline $\mathrm{Ni}(\mathrm{ppm})$ & $<20$ & $20-50$ & $>50$ & $82-143.2$ \\
\hline $\mathrm{Zn}(\mathrm{ppm})$ & $<90$ & $90-200$ & $>200$ & $36.1-76$ \\
\hline
\end{tabular}

*Lower limits not established. 


\section{Correlation Coefficient of Heavy Metals in Soil of the Study Area}

The Pearson's correlation coefficient is a statistical method which describe the strength and direction of the relationship between two variables (Table 7), [36], were employed to evaluate the relations among heavy metals (Table 8), showed strong positive relationships between heavy metals pairs of $\mathrm{Pb}-\mathrm{Zn}(\mathrm{r}=0.894)$, Cr-Ni $(r=0.891)$, Cr-Zn $(r=0.942), \mathrm{Cu}-\mathrm{Ni}(\mathrm{r}=0.859), \mathrm{Cu}-\mathrm{Zn}(\mathrm{r}=0.835), \mathrm{Ni}-$ $\mathrm{Zn}(\mathrm{r}=0.872)$, and $\mathrm{Co}-\mathrm{Cu}(\mathrm{r}=0.810)$. While, the moderate positive relationships observed between heavy metals pairs of $\mathrm{Pb}-\mathrm{Cr}(\mathrm{r}=0.783), \mathrm{Pb}-\mathrm{Ni}(\mathrm{r}$ $=0.733), \mathrm{Cr}-\mathrm{Cu}(\mathrm{r}=0.774), \mathrm{Pb}-\mathrm{Cu}(\mathrm{r}=0.7), \mathrm{Cd}-\mathrm{Cr}(\mathrm{r}=0.705), \mathrm{Cd}-\mathrm{Ni}(\mathrm{r}=$ $0.663)$, Cd-Zn $(\mathrm{r}=0.509)$, Cr-Co $(\mathrm{r}=0.549)$, Co-Ni $(\mathrm{r}=0.547)$, Co-Zn $(\mathrm{r}=$ 0.520). The strong positive relationships among heavy metals indicate to the heavy metals are originated from the same common pollution source is mostly anthropogenic, whereas the weak relationships denoted to differences in geochemical behavior and source of heavy metals [37,38], while the correlations coefficient of $\mathrm{pH}$ with other heavy metals showed no association between them in the soil of the study area, this attributed to the alkaline soil of Shewasoor subbasin (Table 5) [1], also [20] refers to the soil of study area is brown and alkaline soil which content about (1-2)\% of organic matter, where the chemical weathering is play an important role in this layer and potentially affects the bioavailability of heavy metals in the soil of study area.

Table 7: Interpretation of Pearson's Correlation Coefficient [36].

\begin{tabular}{|l|l|}
\hline Correlation value & Strength and Direction of Correlation \\
\hline$(-0.8)-(-1.0)$ & Strongly negative \\
\hline$(-0.5)-(-0.8)$ & Moderately negative \\
\hline$(-0.2)-(-0.5)$ & Weakly negative \\
\hline$(+0.2)-(-0.2)$ & No association \\
\hline$(+0.2)-(+0.5)$ & Weakly positive \\
\hline$(+0.5)-(+0.8)$ & Moderately positive \\
\hline$(+0.8)-(+1.0)$ & Strongly positive \\
\hline
\end{tabular}

Table 8: Pearson's Correlation Matrix Among Heavy Metals in Soil of Study Area.

\begin{tabular}{|c|c|c|c|c|c|c|c|c|c|}
\hline Metal & As & $\mathrm{Pb}$ & $\mathrm{Cd}$ & $\mathrm{Cr}$ & $\mathrm{Co}$ & $\mathrm{Cu}$ & $\mathrm{Ni}$ & $\mathrm{Zn}$ & $\mathrm{pH}$ \\
\hline As & 1 & & & & & & & & \\
\hline $\mathrm{Pb}$ & 0.420 & 1 & & & & & & & \\
\hline $\mathrm{Cd}$ & -0.448 & 0.269 & 1 & & & & & & \\
\hline $\mathrm{Cr}$ & -0.062 & 0.783 & 0.705 & 1 & & & & & \\
\hline $\mathrm{Co}$ & -0.488 & 0.255 & 0.271 & 0.549 & 1 & & & & \\
\hline $\mathrm{Cu}$ & -0.260 & 0.700 & 0.395 & 0.774 & 0.810 & 1 & & & \\
\hline $\mathrm{Ni}$ & -0.233 & 0.733 & 0.663 & 0.891 & 0.547 & 0.859 & 1 & & \\
\hline $\mathrm{Zn}$ & 0.035 & 0.894 & 0.509 & 0.942 & 0.520 & 0.835 & 0.872 & 1 & \\
\hline $\mathrm{pH}$ & 0.315 & 0.380 & -0.206 & -0.017 & -0.253 & 0.152 & 0.070 & 0.148 & 1 \\
\hline
\end{tabular}




\section{Nemerow Pollution Index $\left(\boldsymbol{P}_{N}\right)$}

Degree of heavy metals contamination was evaluated by using Nemerow pollution index $\left(P_{N}\right)$. The results of Nemerow pollution index listed in (Table 9$)$, and spatial distribution of $P_{N}$ shown in (Figure 3). According to [21] the, soil has been moderately contaminated at sites (S1, S2, and S8), whereas the soil has been severely contaminated at all other sites.

Table 9: Ecological Risk Index and Nemerow Pollution Index of Heavy Metals in the Soil of Study Area.

\begin{tabular}{|c|c|l|}
\hline \multirow{2}{*}{$\begin{array}{c}\text { Site } \\
\text { Name }\end{array}$} & $P_{N}$ value & \multicolumn{1}{c|}{ Nemerow pollution index $\left(P_{N}\right)$} \\
\cline { 2 - 3 } S1 & 2.99 & Sontamination Level has been Moderately Contamination \\
\hline S2 & 2.36 & Soil has been Moderately Contamination \\
\hline S3 & 3.80 & Soil has been Severely Contamination \\
\hline S4 & 4.17 & Soil has been Severely Contamination \\
\hline S5 & 3.20 & Soil has been Severely Contamination \\
\hline S6 & 3.10 & Soil has been Severely Contamination \\
\hline S7 & 3.22 & Soil has been Severely Contamination \\
\hline S8 & 2.77 & Soil has been Moderately Contamination \\
\hline$* 2<P_{N<} 3$ Soil has been Moderately Contamination \\
$* P_{N>3}$ Soil has been Moderately Contamination \\
\hline
\end{tabular}

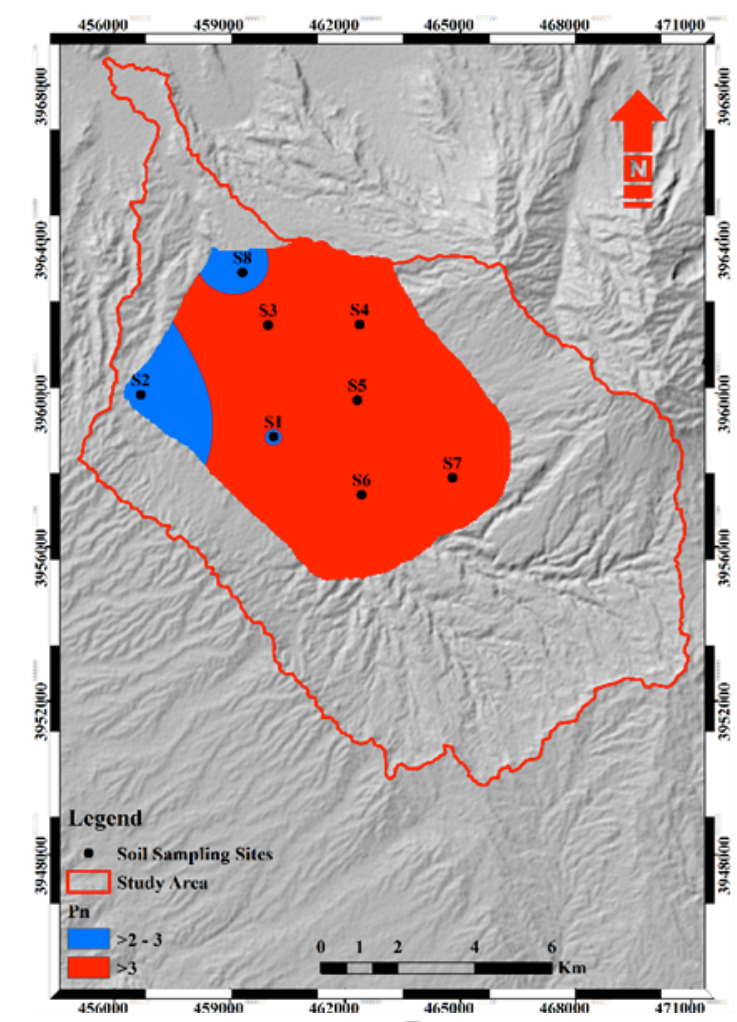

Figure 3. Spatial Distribution of $P_{N}$ in the Soil of Study Area. 


\section{Potential Ecological Risk Index (RI)}

The potential ecological risk index $(R I)$ was used to evaluate the level of ecological risk in the study area. The results of RI showed in (Table 10), and spatial distribution of $R I$ shown in (Figure 4). According to [25], the high level of ecological risk was observed at all sites, except site (S2) which showed moderate ecological risk.

Table 10: Ecological Risk Index and Nemerow Pollution Index of Heavy Metals in the Soil of Study Area.

\begin{tabular}{|c|c|c|}
\hline \multirow{2}{*}{ Site } & \multicolumn{2}{|c|}{ Ecological Risk Index (RI) } \\
\cline { 2 - 3 } Name & RI value & Risk Level \\
\hline S1 & 134.91 & High Risk \\
\hline S2 & 98.92 & Moderate Risk \\
\hline S3 & 120.36 & High Risk \\
\hline S4 & 121.54 & High Risk \\
\hline S5 & 108.41 & High Risk \\
\hline S6 & 145.24 & High Risk \\
\hline S7 & 149.87 & High Risk \\
\hline S8 & 139.63 & High Risk \\
\hline$* 50<$ RI $<100$ Moderate Risk, $* 100<$ RI $<150$ High Risk \\
\hline
\end{tabular}

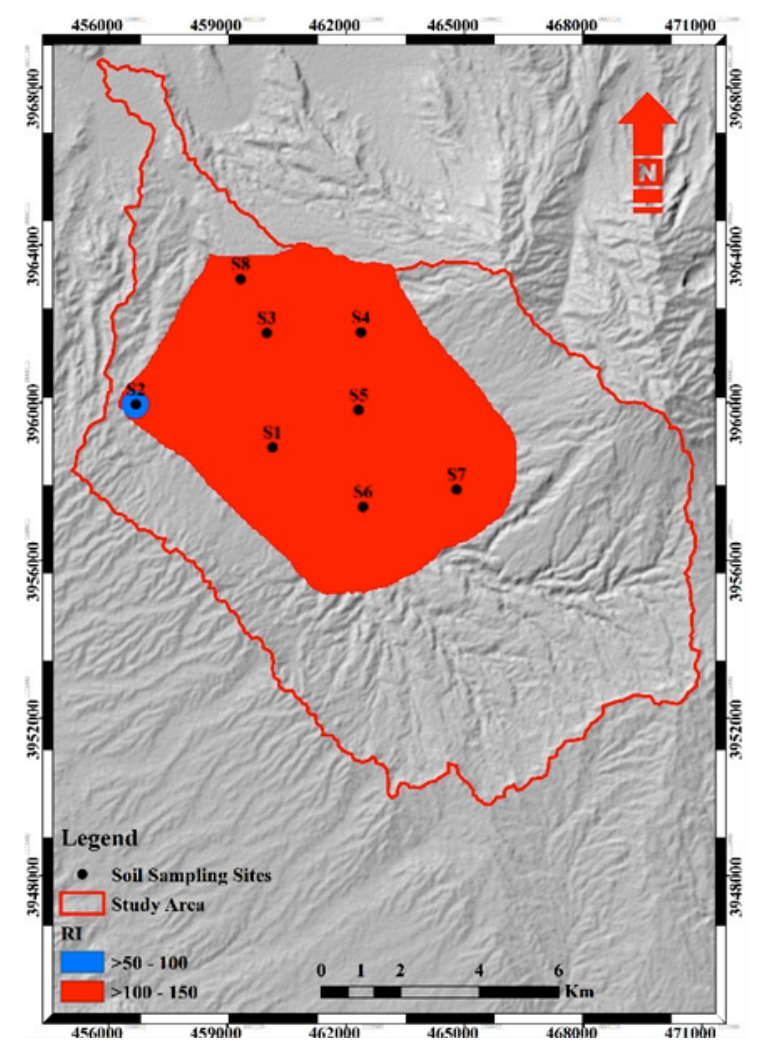

Figure 4. Spatial Distribution of RI in the Soil of Study Area 


\section{Non-carcinogenic Risk Assessment of heavy metals for Adults and children}

The Total Hazard Quotient $(T H Q)$ results of heavy metals present in (Table 11). The non-carcinogenic risk was assessed according to calculated values of Hazard Index $(H I)$ of soil samples for adults and children through different pathways. The results of HI listed in (Table 11), and spatial distribution of $H I$ for adults and children shown in (Figure 5). The $H I$ values for adults at all sites were observed lower than one $(H I<1)$, this means there is no non-carcinogenic risk for adults, and the adults population were unlikely to experience adverse effects. Whereas the $H I$ values for children higher than one $(H I>1)$ at all sampling sites, this mean the children that reside in the study area were at risk of non-carcinogenic effects of heavy metals.

Table 11: Total Hazard Quotient and Hazard Index of Heavy Metals for Adults and Children in Soil of Study Area.

\begin{tabular}{|c|c|c|c|c|c|c|c|c|c|c|}
\hline & \multirow{2}{*}{$\begin{array}{l}\text { Site } \\
\text { Name }\end{array}$} & \multicolumn{8}{|c|}{ Total Hazard Quotient (THQ) } & \multirow[t]{2}{*}{ Hazard Index (HI) } \\
\hline & & As & $\mathrm{Pb}$ & $\mathrm{Cd}$ & $\mathrm{Cr}$ & Co & $\mathrm{Cu}$ & $\mathrm{Ni}$ & $\mathrm{Zn}$ & \\
\hline \multirow{8}{*}{$\frac{\stackrel{n}{E}}{\vec{E}}$} & $\mathrm{~S} 1$ & $3.8 \mathrm{E}-02$ & $4.0 \mathrm{E}-03$ & $9.0 \mathrm{E}-04$ & $4.2 \mathrm{E}-02$ & $8.1 \mathrm{E}-02$ & $8.0 \mathrm{E}-04$ & $9.1 \mathrm{E}-03$ & $2.3 \mathrm{E}-04$ & 0.177 \\
\hline & $\mathrm{S} 2$ &, $3.0 \mathrm{E}-02$ & $3.2 \mathrm{E}-03$ & $6.2 \mathrm{E}-04$ & $3.3 \mathrm{E}-02$ & $9.3 \mathrm{E}-02$ & $8.8 \mathrm{E}-04$ & 7.3E-03 & $1.7 \mathrm{E}-04$ & 0.168 \\
\hline & S3 & $4.9 \mathrm{E}-02$ & $5.3 \mathrm{E}-03$ & $6.0 \mathrm{E}-04$ & $4.2 \mathrm{E}-02$ & $8.8 \mathrm{E}-02$ & $1.0 \mathrm{E}-03$ & $1.0 \mathrm{E}-02$ & $2.6 \mathrm{E}-04$ & 0.196 \\
\hline & S4 & $5.5 \mathrm{E}-02$ & $4.3 \mathrm{E}-03$ & $6.0 \mathrm{E}-04$ & $3.4 \mathrm{E}-02$ & $6.6 \mathrm{E}-02$ & $6.7 \mathrm{E}-04$ & $6.4 \mathrm{E}-03$ & $1.8 \mathrm{E}-04$ & 0.168 \\
\hline & S5 & $4.1 \mathrm{E}-02$ & $4.5 \mathrm{E}-03$ & $5.8 \mathrm{E}-04$ & $3.7 \mathrm{E}-02$ & $7.5 \mathrm{E}-02$ & $8.6 \mathrm{E}-04$ & $8.4 \mathrm{E}-03$ & $2.4 \mathrm{E}-04$ & 0.168 \\
\hline & S6 & $3.9 \mathrm{E}-02$ & $4.9 \mathrm{E}-03$ & $9.6 \mathrm{E}-04$ & 4.3E-02 & $7.9 \mathrm{E}-02$ & $9.5 \mathrm{E}-04$ & $1.0 \mathrm{E}-02$ & $2.6 \mathrm{E}-04$ & 0.178 \\
\hline & S7 & $4.0 \mathrm{E}-02$ & $5.8 \mathrm{E}-03$ & $9.9 \mathrm{E}-04$ & $5.3 \mathrm{E}-02$ & $1.0 \mathrm{E}-01$ & $1.2 \mathrm{E}-03$ & $1.1 \mathrm{E}-02$ & $3.5 \mathrm{E}-04$ & 0.213 \\
\hline & S8 & $3.5 \mathrm{E}-02$ & $4.4 \mathrm{E}-03$ & $9.5 \mathrm{E}-04$ & $4.2 \mathrm{E}-02$ & $8.1 \mathrm{E}-02$ & $9.4 \mathrm{E}-04$ & $1.0 \mathrm{E}-02$ & $2.3 \mathrm{E}-04$ & 0.174 \\
\hline \multirow{8}{*}{ 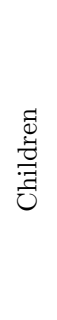 } & S1 & $3.1 \mathrm{E}-01$ & 3.7E-02 & $6.8 \mathrm{E}-03$ & $3.8 \mathrm{E}-01$ & $7.5 \mathrm{E}-01$ & 7.4E-03 & $8.1 \mathrm{E}-02$ & $2.1 \mathrm{E}-03$ & 1.576 \\
\hline & S2 & $2.5 \mathrm{E}-01$ & $3.0 \mathrm{E}-02$ & $4.6 \mathrm{E}-03$ & $2.9 \mathrm{E}-01$ & $8.6 \mathrm{E}-01$ & $8.2 \mathrm{E}-03$ & $6.5 \mathrm{E}-02$ & $1.5 \mathrm{E}-03$ & 1.511 \\
\hline & S3 & $4.0 \mathrm{E}-01$ & $5.0 \mathrm{E}-02$ & $4.1 \mathrm{E}-03$ & 3.7E-01 & $8.2 \mathrm{E}-01$ & $9.6 \mathrm{E}-03$ & $8.9 \mathrm{E}-02$ & $2.4 \mathrm{E}-03$ & 1.747 \\
\hline & S4 & $4.5 \mathrm{E}-01$ & $4.0 \mathrm{E}-02$ & $4.3 \mathrm{E}-03$ & $3.1 \mathrm{E}-01$ & $6.2 \mathrm{E}-01$ & $6.3 \mathrm{E}-03$ & $5.7 \mathrm{E}-02$ & $1.7 \mathrm{E}-03$ & 1.480 \\
\hline & S5 & $3.4 \mathrm{E}-01$ & $4.2 \mathrm{E}-02$ & $4.1 \mathrm{E}-03$ & $3.3 \mathrm{E}-01$ & $7.0 \mathrm{E}-01$ & $8.0 \mathrm{E}-03$ & $7.5 \mathrm{E}-02$ & $2.2 \mathrm{E}-03$ & 1.497 \\
\hline & S6 & $3.2 \mathrm{E}-01$ & $4.6 \mathrm{E}-02$ & 7.3E-03 & $3.8 \mathrm{E}-01$ & 7.3E-01 & $8.9 \mathrm{E}-03$ & $9.1 \mathrm{E}-02$ & $2.4 \mathrm{E}-03$ & 1.587 \\
\hline & S7 & $3.3 \mathrm{E}-01$ & $5.4 \mathrm{E}-02$ & 7.3E-03 & 4.7E-01 & $9.3 \mathrm{E}-01$ & $1.1 \mathrm{E}-02$ & $9.9 \mathrm{E}-02$ & $3.2 \mathrm{E}-03$ & 1.905 \\
\hline & S8 & $2.8 \mathrm{E}-01$ & $4.1 \mathrm{E}-02$ & 7.3E-03 & $3.8 \mathrm{E}-01$ & $7.5 \mathrm{E}-01$ & $8.8 \mathrm{E}-03$ & $8.9 \mathrm{E}-02$ & $2.2 \mathrm{E}-03$ & 1.555 \\
\hline
\end{tabular}




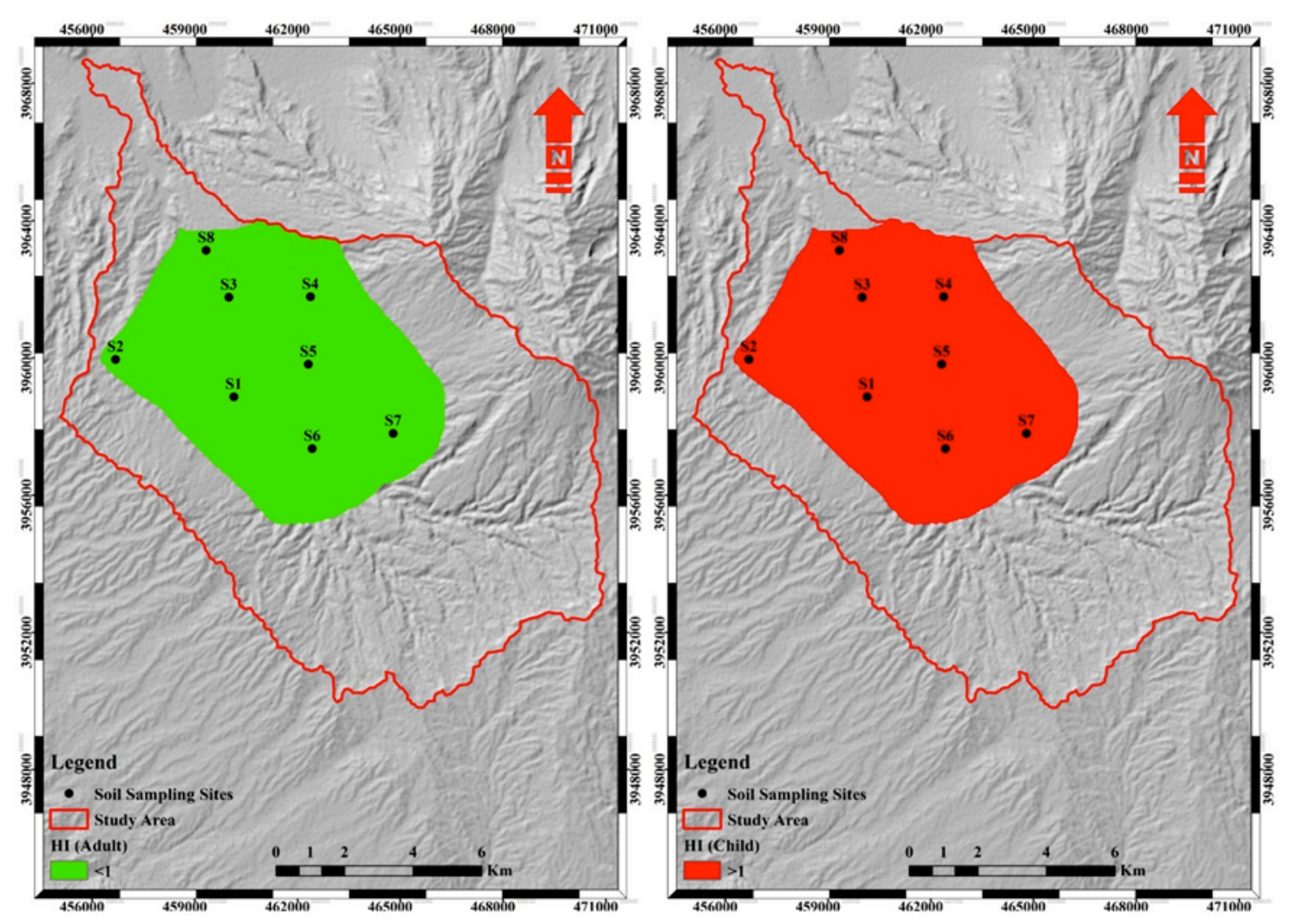

Figure 5. Spatial Distribution of $H I$ for Adults and Children in the Soil of Study Area.

Carcinogenic Risk Assessment of Heavy Metals for Adults and Children

The cancer risk for heavy metals $\mathrm{As}, \mathrm{Pb}, \mathrm{Cd}, \mathrm{Cr}, \mathrm{Co}$, and $\mathrm{Ni}$ were calculated, these metals are most contributors to the cancer risk, the results were shown in (Table 12). The total cancer risk values of As and $\mathrm{Cr}$ for adults and children were in acceptable risk range at all sampling sites, while the total cancer risk of $\mathrm{Pb}, \mathrm{Cd}, \mathrm{Co}$, and $\mathrm{Ni}$ was lower than tolerable risk range at all sites. These values mean there is no cancer risk for adults and children, which they residing in the study area. 
Table 12: Total Cancer Risk of Heavy Metals in Soil of Study Area.

\begin{tabular}{|c|c|c|c|c|c|c|c|c|c|}
\hline & \multirow{2}{*}{$\begin{array}{c}\text { Site } \\
\text { Name }\end{array}$} & \multicolumn{8}{|c|}{ Total Cancer Risk } \\
\hline & & As & $\mathrm{Pb}$ & $\mathrm{Cd}$ & $\mathrm{Cr}$ & $\mathrm{Co}$ & $\mathrm{Cu}$ & $\mathrm{Ni}$ & $\mathrm{Zn}$ \\
\hline \multirow{8}{*}{$\begin{array}{l}\frac{n}{3} \\
\frac{7}{4}\end{array}$} & $\mathrm{~S} 1$ & $6.6 \mathrm{E}-06$ & $5.0 \mathrm{E}-08$ & $3.8 \mathrm{E}-14$ & $2.7 \mathrm{E}-05$ & $1.3 \mathrm{E}-11$ & - & $2.6 \mathrm{E}-12$ & - \\
\hline & $\mathrm{S} 2$ & $5.2 \mathrm{E}-06$ & 4.0E- 08 & $2.6 \mathrm{E}-14$ & $2.1 \mathrm{E}-05$ & $1.5 \mathrm{E}-11$ & - & $2.1 \mathrm{E}-12$ & - \\
\hline & S3 & $8.6 \mathrm{E}-06$ & $6.8 \mathrm{E}-08$ & $2.3 \mathrm{E}-14$ & $2.7 \mathrm{E}-05$ & $1.4 \mathrm{E}-11$ & - & $2.8 \mathrm{E}-12$ & - \\
\hline & $\mathrm{S} 4$ & $9.6 \mathrm{E}-06$ & $5.5 \mathrm{E}-08$ & $2.4 \mathrm{E}-14$ & $2.2 \mathrm{E}-05$ & $1.1 \mathrm{E}-11$ & - & $1.8 \mathrm{E}-12$ & - \\
\hline & S5 & 7.2E-06 & $5.8 \mathrm{E}-08$ & $2.3 \mathrm{E}-14$ & $2.4 \mathrm{E}-05$ & $1.2 \mathrm{E}-11$ & - & $2.4 \mathrm{E}-12$ & - \\
\hline & S6 & $6.8 \mathrm{E}-06$ & $6.3 \mathrm{E}-08$ & $4.1 \mathrm{E}-14$ & $2.7 \mathrm{E}-05$ & $1.3 \mathrm{E}-11$ & - & $2.9 \mathrm{E}-12$ & - \\
\hline & S7 & $7.0 \mathrm{E}-06$ & 7.3E-08 & $4.1 \mathrm{E}-14$ & $3.4 \mathrm{E}-05$ & $1.6 \mathrm{E}-11$ & - & $3.1 \mathrm{E}-12$ & - \\
\hline & S8 & $6.0 \mathrm{E}-06$ & $5.7 \mathrm{E}-08$ & $4.1 \mathrm{E}-14$ & $2.7 \mathrm{E}-05$ & $1.3 \mathrm{E}-11$ & - & $2.8 \mathrm{E}-12$ & - \\
\hline \multirow{8}{*}{ 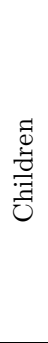 } & S1 & $1.2 \mathrm{E}-05$ & $9.4 \mathrm{E}-08$ & $1.8 \mathrm{E}-14$ & $4.9 \mathrm{E}-05$ & $6.2 \mathrm{E}-12$ & - & $1.2 \mathrm{E}-12$ & - \\
\hline & $\mathrm{S} 2$ & $9.4 \mathrm{E}-06$ & $7.5 \mathrm{E}-08$ & $1.2 \mathrm{E}-14$ & $3.8 \mathrm{E}-05$ & 7.1E-12 & - & $9.6 \mathrm{E}-13$ & - \\
\hline & S3 & 1.6E-05 & $1.3 \mathrm{E}-07$ & $1.1 \mathrm{E}-14$ & $4.8 \mathrm{E}-05$ & $6.7 \mathrm{E}-12$ & - & $1.3 \mathrm{E}-12$ & - \\
\hline & $\mathrm{S} 4$ & $1.7 \mathrm{E}-05$ & $1.0 \mathrm{E}-07$ & $1.1 \mathrm{E}-14$ & $3.9 \mathrm{E}-05$ & $5.1 \mathrm{E}-12$ & - & $8.3 \mathrm{E}-13$ & - \\
\hline & S5 & $1.3 \mathrm{E}-05$ & $1.1 \mathrm{E}-07$ & $1.1 \mathrm{E}-14$ & $4.2 \mathrm{E}-05$ & $5.7 \mathrm{E}-12$ & - & 1.1E-12 & - \\
\hline & S6 & 1.2E- 05 & $1.2 \mathrm{E}-07$ & $1.9 \mathrm{E}-14$ & $4.9 \mathrm{E}-05$ & $6.0 \mathrm{E}-12$ & - & 1.3E-12 & - \\
\hline & S7 & 1.3E-05 & $1.4 \mathrm{E}-07$ & $1.9 \mathrm{E}-14$ & $6.0 \mathrm{E}-05$ & 7.7E-12 & - & $1.5 \mathrm{E}-12$ & - \\
\hline & S8 & $1.1 \mathrm{E}-05$ & $1.1 \mathrm{E}-07$ & $1.9 \mathrm{E}-14$ & $4.8 \mathrm{E}-05$ & $6.2 \mathrm{E}-12$ & - & 1.3E-12 & - \\
\hline
\end{tabular}

\section{Conclusion}

In the current research several environmental indices were used to the assessment of heavy metals contamination levels in the soil of study area, the results of this study summarized as follow:

1) The abundance trend of median concentrations of heavy metals increasing in order of $\mathrm{Ni}>\mathrm{Cr}>\mathrm{Zn}>\mathrm{Cu}>\mathrm{Co}>\mathrm{Pb}>\mathrm{As}>\mathrm{Cd}$. The concentrations of $\mathrm{As}, \mathrm{Cd}$, and $\mathrm{Ni}$ highest than geochemical background values at all sites, whereas concentrations of $\mathrm{Pb}, \mathrm{Cr}, \mathrm{Co}$, and $\mathrm{Zn}$ are lower than the geochemical background values, except $\mathrm{Zn}$ at $\mathrm{S} 7$ exceeded the same background value. The comparison of heavy metals concentration with U.S. SQGs, where all sites non-polluted with $\mathrm{Pb}, \mathrm{Cd}$, and $\mathrm{Zn}$, and polluted heavily by $\mathrm{Ni}$, whereas $\mathrm{S} 6, \mathrm{~S} 7$, and $\mathrm{S} 8$ are polluted moderately with $\mathrm{As}$ and $\mathrm{Cu}$, but polluted heavily by $\mathrm{Cr}$. The Concentrations of As, $\mathrm{Pb}, \mathrm{Cd}$, and $\mathrm{Cu}$ are lower than Ecological Screening values, and concentrations of $\mathrm{Cr}, \mathrm{Co}, \mathrm{Ni}$, and $\mathrm{Zn}$ are higher than Ecological Screening values at all sites, except $\mathrm{Zn}$ at $\mathrm{S} 1, \mathrm{~S} 2$, and $\mathrm{S} 4$ is lower than the same value. The concentrations of $\mathrm{As}, \mathrm{Pb}, \mathrm{Cd}, \mathrm{Cr}, \mathrm{Co}, \mathrm{Cu}$, and $\mathrm{Zn}$ at all sites lower than WHO guidelines, except $\mathrm{Ni}$ its concentrations higher than the same guidelines.

2) The Pearson's correlation coefficient analysis showed there are strong positive relationships among $\mathrm{Pb}, \mathrm{Co}, \mathrm{Cu}, \mathrm{Zn}, \mathrm{Cr}$, and $\mathrm{Ni}$ indicates to these heavy metals originated from the same pollution source which is mostly anthropogenic, while the weak positive relationships were observed between pairs $(\mathrm{As}-\mathrm{Pb}),(\mathrm{Cd}-$ $\mathrm{Cu}),(\mathrm{Pb}-\mathrm{Cd}),(\mathrm{Cd}-\mathrm{Co})$, and $(\mathrm{Pb}-\mathrm{Co})$ which indicate to these heavy metals come from different pollution source, whereas the weak negative relationship found between $\mathrm{As}$ with $\mathrm{Cd}, \mathrm{Co}, \mathrm{Cu}$, and $\mathrm{Ni}$, also there is no association between $\mathrm{pH}$ and heavy metals which attributed to the alkaline soil of study area. 
3) The $R I$ showed high risk at all sites, except site $(\mathrm{S} 2)$, while according to $P_{N}$ the soil has been moderately contaminated at sites (S1, S2, and S8), and severely contaminated at other sites.

4) The $H I$ showed there are no noncarcinogenic adverse effects for adults, but the children are at risk of non-carcinogenic effects. While the total cancer risk values of As and $\mathrm{Cr}$ within acceptable range for adults and children, whereas for $\mathrm{Pb}, \mathrm{Cd}, \mathrm{Co}$, and $\mathrm{Ni}$ were lower than tolerable risk range at all sites.

Ecological indices in the current study gives similar results, which refers to the soil of study area contaminated moderate to heavily by heavy metals, this attributed to many pollution sources which are enrich the study area by heavy metals. The natural pollution sources are: 1) weathering, erosion, and leaching processes of rocks and sediments, 2) atmospheric deposition of pollutants (i.e. dust particles and rainwater). In other hand, the Anthropogenic pollution sources are: 1) agricultural activities (i.e. using of organic or inorganic fertilizers, pesticides, and nutrients) these materials contain amounts of heavy metals, 2) livestock breeding, the animal wastes also contribute to pollute the soil of study area, 3) because of there is no wastewater and sewage sludge discharge nets in the area, the population are discharge these wastes to open areas, hence pollute areas of soil in the study area. The soil pollution at these levels have negative effects on the human health which are residing in the study area.

\section{References:}

1. Van der Perk M. Soil and Water Contamination. Taylor \& Francis/Balkema Group plc, London, UK; 2006;389 p.

2. Bullock P, Gregory PJ. Soils in the urban environment. John Wiley \& Sons; 2009.

3. Nriagu JO, Pacyna JM. Quantitative assessment of worldwide contamination of air, water and soils by trace metals. Nature. 1988;333(6169):134-9.

4. Li Z, Ma Z, van der Kuijp TJ, Yuan Z, Huang L. A review of soil heavy metal pollution from mines in China: pollution and health risk assessment. Sci Total Environ. 2014;468:843-53.

5. Li Q, Chen Y, Fu H, Cui Z, Shi L, Wang L et al. Health risk of heavy metals in food crops grown on reclaimed tidal flat soil in the Pearl River Estuary, China. J. Hazard Mater. 2012;227-228:148-154.

6. Zhao H, Xia B, Fan C, Zhao P, Shen S. Human health risk from soil heavy metal contamination under different land uses near Dabaoshan Mine, Southern China. Sci Total Environ. $2012 ; 417: 45-54$.

7. Abdelhafez AA, Abbas HH, Abd - El - Aal RS, Kandil NF, Li J, Mahmoud W. Environmental and health impacts of successive mineral fertilization in Egypt. CLEAN-Soil, Air, Water. 2012;40(4):356-63.

8. Harikumar PS, Prajitha K, Silpa S. Assessment of Heavy Metal Contamination in the Sediments of a River Draining into a Ramsar site in the India Sub Continent. Vol. I. Journal of Advanced Laboratory Research in Biology. 2010;120-129.

9. Nouri J, Mahvi AH, Babaei A, Ahmadpour E. Regional pattern distribution of groundwater fluoride in the Shush aquifer of Khuzestan County, Iran. Fluoride. 2006;39(4):321-325.

10. Pekey H. Heavy metal pollution assessment in sediments of the Izmit Bay, Turkey. Environ. Monit. Assess. 2006;123(1-3):219-231.

11. Nicholson FA, Smith SR, Alloway BJ, Carlton-Smith C, Chambers BJ. An inventory of heavy metals inputs to agricultural soils in England and Wales. Sci Total Environ. 2003;311(13):205-19.

12. Campbell LM. Mercury in Lake Victoria (East Africa): Another emerging issue for a beleaguered lake? Ph.D. dissertation, Waterloo, Ontario, Canada. 2003.

13. Lane TW, Morel FM. A biological function for cadmium in marine diatoms. Proc. Natl. Acad. Sci. USA. 2009 
14. Kabata-Pendias A. Trace Elements in Soil and Plants (4th Eds.). Boca Raton, CRC press, Washington, DC; 2011.

15. Wang J, Cui L, Gao W, Shi T, Chen Y, Gao Y. Prediction of low heavy metal concentrations in agricultural soils using visible and near-infrared reflectance spectroscopy. Geoderma. $2014 ; 216: 1-9$.

16. Jaradat AA. Agriculture in Iraq: Resources, Potentials, Constraints, and Research Needs and Priorities. NCSC Research Lab, ARS-USDA 803 Iowa Avenue, Morris, MN 56267. 2002;83 p.

17. Sissakian VK. The Geology of Kirkuk Quadrangle. Sheet NI-38-2, scale 1: 250 000. GEOSURV, Baghdad, Iraq; 1992; 48 p.

18. Al-Naqib KM. Southern Region Geology Summary for the brigade Kirkuk-Iraq, Iraq Oil Company Limited. Second Arab Petroleum conference. 1960; pp. 62.

19. Al-Kadhimi JA, Sissakian VK, Deikran DB, Fattah AS. Tectonic Map of Iraq, Scale 1:1000000, 2nd edition. GEOSURV, Baghdad, Iraq. 1996.

20. Buringh P. Soils and soil conditions in Iraq. Ministry of agriculture; 1960; 332 p.

21. Chen H, An J, Wei S, Gu J. Spatial patterns and risk assessment of heavy metals in soils in a resource-exhausted city, Northeast China. PLoS One. 2015;10(9):e0137694.

22. Wedepohl KH. The composition of the continental crust. Geochim Cosmochim Acta. 1995;59(7):1217-32.

23. Bade R, Oh S, Shin WS, Hwang I. Human health risk assessment of soils contaminated with metal (loid) s by using DGT uptake: A case study of a former Korean metal refinery site. Hum Ecol Risk Assess An Int J. 2013;19(3):767-77.

24. Khan MN, Wasim AA, Sarwar A, Rasheed MF. Assessment of heavy metal toxicants in the roadside soil along the N-5, National Highway, Pakistan. Environ Monit Assess. 2011;182(1-4):587-95.

25. Hakanson L. An ecological risk index for aquatic pollution control. A sedimentological approach. Water Res. 1980;14(8):975-1001.

26. U. S. Environmental Protection Agency (U.S. EPA). Toxics Release Inventory: Public Data Release Report. 2001. Online available at <www.epa.gov/tri/tridata/tri01 $>$. (accessed 24 February 2015).

27. Council NR. Risk assessment in the federal government: managing the process. National Academies Press, Washington, D.C. USA; 1983.

28. U. S. Environmental Protection Agency (U.S. EPA). Risk Assessment Guidance for Superfund Volume 1: Human Health Evaluation Manual (Part A). Office of Emergency and Remedial Response: Washington, D.C., USA; 1989.

29. U. S. Environmental Protection Agency (U.S. EPA). Regional Screening Levels prepared by Oak Ridge National Laboratories. 2016. Online available at <http://epaprgs.ornl.gov/chemicals/index.shtml>.

30. U. S. Environmental Protection Agency (U.S. EPA). Regional Screening Level (RSL) Summary Table. 2017. Online available at <https://www.epa.gov/risk/regional-screening-levels-rslsgeneric-tables-june-2017>.

31. U. S. Environmental Protection Agency (U.S. EPA). Risk Assessment Guidance for Superfund Volume I: Human Health Evaluation Manual (Part E, Supplemental Guidance for Dermal Risk Assessment); USEPA: Washington, D.C., USA; 2004.

32. MOE. Soil contamination risk assessment guidelines. Korean Ministry of Environment, Gwachun, Kyunggi in South Korea. 2009.

33. Friday GP. Ecological screening values for surface water, sediment, and soil: 2005 Update. Savannah River Site (SRS), Aiken, SC; 2005.

34. Chiroma TM, Ebewele RO, Hymore K. Comparative assessment of heavy metal levels in soil, vegetables and urban grey wastewater used for irrigation in Yola and Kano. Int. Ref. J. Eng. Sci. 2014; 3:1-9.

35. U. S. Environmental Protection Agency (U.S. EPA). Guidance for the Pollutional Classification of Great Lakes Harbor Sediments, Region V, Chicago, Illinois; 1977.

36. Zou KH, Tuncali K, Silverman SG. Correlation and simple linear regression. Radiology. 2003;227(3):617-28.

37. Manta DS, Angelone M, Bellanca A, Neri R, Sprovieri M. Heavy metals in urban soils: a case study from the city of Palermo (Sicily), Italy. Sci Total Environ. 2002;300(1-3):229-43.

38. Yang Z, Lu W, Long Y, Bao X, Yang Q. Assessment of heavy metals contamination in urban topsoil from Changchun City, China. J Geochemical Explor. 2011;108(1):27-38. 


\section{List of Abbreviation}

\begin{tabular}{|c|c|}
\hline Abbreviation & Meaning \\
\hline ArcGIS & $\begin{array}{l}\text { Aeronautical Reconnaissance Coverage Geographic } \\
\text { Information System }\end{array}$ \\
\hline$C$ & Concentration \\
\hline CDI & Chronic Daily Intake \\
\hline $\mathbf{C m}$ & Centimeter \\
\hline$C R$ & Carcinogenic Risks \\
\hline$C S F$ & Chronic Slope Factor \\
\hline gm & Gram \\
\hline$H I$ & Hazard Index \\
\hline$H Q$ & Hazard Quotient \\
\hline ICP-MS & Inductively Coupled Plasma-Mass Spectrometry \\
\hline IDW & Inverse Distance Weighted \\
\hline$I U R$ & Inhalation Unit Risk \\
\hline $\mathbf{K m}$ & Kilometer \\
\hline $\mathbf{m}$ & Meter \\
\hline m a.s.l. & Meter Above Sea level \\
\hline Max & Maximum \\
\hline $\mathbf{m E}$ & Meter to East \\
\hline $\mathrm{Mg} / \mathrm{m}^{3}$ & Milligram/Cubic meter \\
\hline Min & Minimum \\
\hline MOE & Ministry of Environment \\
\hline $\mathbf{m N}$ & Meter to North \\
\hline$\mu \mathrm{g} / \mathrm{m}^{3}$ & Microgram/Cubic meter \\
\hline NRC & National Research Council \\
\hline$P I$ & Pollution Index \\
\hline$P_{N}$ & Nemerow Pollution Index \\
\hline ppm & Part Per Million \\
\hline$R f D$ & Reference Dose \\
\hline $\boldsymbol{R I}$ & Potential Ecological Risk Index \\
\hline SQGs & Sediment Quality Guidelines \\
\hline $\mathbf{K m}^{2}$ & Square Kilometer \\
\hline$T_{i}$ & Toxicity factor \\
\hline U.S. EPA & United States Environmental Protection Agency \\
\hline WHO & World Health Organization \\
\hline
\end{tabular}

